\title{
Biological Industrial Policy of Japan and Republic of Korea
}

\author{
Li Guijie, Wang Qiang \\ Department of biological and Chemical Engineering, Chongqing University of Education, Chongqing, China \\ quajetlee@gmail.com
}

\begin{abstract}
This essay analyzes the history and status quo of biological-industry policies in Japan and Republic of Korea. The Japanese government propels the development of biological industry by optimizing development strategies, increasing investment, promoting the combination of government, industry and schools, paying attention to products and market expectations and so on, while Republic of Korea guides and promotes biological industry to grow stronger by making strategic focuses clear, making scientific planning and management, supporting technological innovations to be industrialized, diversifying cooperative operation and so. Based on the national condition of Japan and Republic of Korea, their future polices directions and development priorities were discussed in order to provide a reference for the development of biological industry in China. policy

Index Terms - Japan, Republic of Korea, biological industry,
\end{abstract}

\section{JAPAN}

Japan ranks among the top in the field of biotechnology all over the world. Since December 2002, the Japanese government had proposed the aim that "the nation relies upon biotechnology industry" [1], and sped up to develop biological technology and industry by implementing optimizing development strategy, increasing capital investment, promoting the combination of government, industry and schools, etc. With the continuous innovation and great breakthroughs in biological technology, certain industries such as biological agriculture, biological medicine, food, biological chemistry, marine and biological environmental protection, have reached to the leading position in the world.

\section{A. Make Overall Planning and Optimize Biotechnology Development Strategy}

Since the 1980s, Japan began to pay attention to the overall planning of biological technology and industry. Departments including MITI, The Ministry of Science and Technology, The Ministry of Education, The Ministry of Agriculture, Forestry and Fisheries and The Ministry of Welfare have successively formulated the "Biotechnology 10-year Plan (1981)", "Biological Materials Research Program (1986)", "Biochip Plan (1987)", "Sugar Engineering Research Program (1991)", "National Biotechnology Strategy(2002)", "Fundamental Strategy to Found Biotechnology Industry (2004)", "Biomass Industrialization Strategy (2012)" and so on. In 2001, 59 national institutes started to independently run the power of management. In 2009, biology industry association of Japan called this year as "the renewable year of biological industry" in order to further increase the drive of biological industry.

\section{B. Integration of the Internal and the External and Overall Coordination between the Development of Research and Industry}

In Japan, the government advocates promoting the combination of government, industry, universities and institutes in order to urge the rapid transformation of scientific researches and achievements. It is showed from data of Japan Biotechnological-industry Association (JBA) that in Japan, more than $80 \%$ scientific and technological investment come from Japan's private enterprises and more than $65 \%$ scientific researchers work in corporations. Enterprises play a supporting role for biotechnological development. Meanwhile, industrialization of biological technology provides momentum for their development. In addition, Japan also put special emphasis on overall coordination between biotechnology and its industry, and form the cooperative research industrial mechanism combined by medicine and engineering. More than 70 large companies and over 20 large-scale equipment manufacturing factory joint together as life science committee to avoid the repetition and waste of the researches. In abroad, Japan continues to strengthen international cooperation in the field of biotechnology, such as completion of human genome sequencing with the United States, Britain, Germany, France and China, completion of the chimpanzee chromosome 22 gene sequencing in cooperation with China and Germany, participation in the international rice genome sequencing project, in which Japan has studied the 32,000 gene base pairs, and accumulated a lot of research data. These research results are quickly applied to the industrial development.

\section{Increase Investment and Capital Budget Continuously}

In 1990, the fund for biotechnological research and development of Japan was 290 billion yen, and in spite of the slump at home, the budget for biotechnological research and development of Japan government was still up to 254.1 billion yen in 2007, 302.5 billion in 2008 and 356.5 billion yen in $2009[2,3]$. In addition, the government set up a special plan and organized the relevant departments to jointly support the effective integration of resources on the field of biotechnology that they have advantages internationally in order to speed up development of the advantageous area and propel biological industry that has international competitive ability. Departments including The Ministry of Education, Ministry of Economy, Trade and Industry, The Ministry of Welfare give strong support and the special funds to those projects, such as fermentation engineering, development of functional food, environmental protection, energy conservation and emission 
reduction, monoclonal antibody drug preparation, bioenergy conversion, animal cloning, transgenic plant industry as well as biological service.

\section{Emphasize Conversion and Provide more Opportunities for Development of Biological Enterprises}

The Japan government encourages the universities to found new companies. Since 2004, to strengthen the independent commercialization capability of universities and research institutes, the government performed comprehensive reform of universities and research institutions by slashing financial support to 85 institutes $[2,4]$. Trading is an important part for the development of biological enterprises. In Japan, however, the minimum qualification of a listed company is to own 200 million yen net assets, which will no doubt leave out of those new-start biological enterprises because they have high costs in the starting stage and need for a large amount of money. To promote biological enterprise to get listed and financial support, Japan began to carry out the counter registration special stock system since 1995. By measuring the proportion of fund for research and development in the enterprise sales as the condition to evaluate whether a company can be listed. It also gradually adjusted evaluation measure for public price of the shares and protected biotechnology companies by reforming access mechanism to the financial market. The government also revised and perfected the laws and regulations, such as Commercial Law, Drug Transaction Law, Intellectual Property Law etc. $[3,5]$, provide powerful guarantee in law for the development of enterprises.

\section{E. Foresights on Technologies and the Key Research Areas}

Foresight on technologies refers to a systematic research on science, technology, economic and social development in a rather long period so as to determine the strategic research field and choose the general technology with the greatest contribution to economic and social development. Related biological industry has the characteristics such as the high investment and long period as well as high uncertain output. To evaluate the biological industry is beneficial to decide the key funded projects, utilize resources rationally and avoid risks effectively [6]. Since 1971, Japan holds an activity for technological foresight every five years. It has been eight times so far and the activities successfully guide and implement the forecast of the key areas and the direction of development.

\section{Republic of Korea}

Following the success of consumer electronic industry, heavy industry and information technology industry, Republic of Korea develops biological science and technology in order to write the brilliancy consecutively. After entering into the 21 st century, Korean government regarded it as the new engine to lead economic development. Through macroscopic planning, policy and financial support, it guides and supports the development of biological industry. Currently, Korea has been or near to the world's advanced level in the fields such as fermentation, the stem cells, anti-HIV vaccine as well as the resistant crops.

\section{A. Clear Strategy and Focus}

The Korea biological industrial policy is based on the practical application, and it also takes occupying the strategic high ground into consideration. Government makes the "three-steps" strategy, that is, the first step is to support of application of the technological achievements, the second step is to encourage the introduction of international advanced technology and product and the third step is to stimulate the original innovation. According to the strategy, the government completes a series of strategic deployment, including incorporation of biological science and technology into national development planning (1982), enactment of Biological Technology Promoting Act (1983), the building of biotechnology major in universities and research institutions (1984), the issuing of CRI (1997), promoting Science and Technology Fundamental Plan (2001-2006), the launch of Next Generation Driving Engine Project (2004). To cultivate special biological industry and the highest input and output ratio out of limited funds, Republic of Korea supports different fields in biological industry with different strength and has clear focus. Maintaining as the leader in fermentation engineering, the government invests more on projects such as biological medicine and biological energy. In 2005, Department of Industry Resources of Korean explicitly pointed out in its Biological Industry Developing Strategy that it was important to focus on key projects such as stem cell cloning and genetic recombination, improve the production efficiency of transgenic products, develop new type modified biotechnology products in order to broaden the financing channels and to attract the public and private institutions to invest in the biological industry $[7,8]$.

\section{B. Encourage Innovation and Promote Industrialization}

Republic of Korea realizes that Innovation is the drive and source of development and there is a big gap between Korea and the developed countries in the field of biological innovation. Thus since the end of 1990s, the government has issued series of plans, including NAL (1999), " $21^{\text {st }}$-century Cutting-edge Research and Development Project (2000) in order to encourage the development of biological science and technology at home and promote original innovation ability. To accelerate the industrialization of scientific research achievements, at the beginning of 2003, the government started to carry out "Bio-Star Plan" which emphasized the industrialization of applied researches [10]. In 2003, the Ministry of Commerce, the Ministry of Industry and the Department of Energy jointly held a development and strategy meeting for biological industry and made the announcement as "Promote Biological Industry, New Drug Research and Development, Organ Engineering and Biological Chip Development Project".

\section{Scientific Management and Reasonable Planning}

Biological industry affairs involved eight government departments including the Department of Commerce, Industry 
and Energy, the Ministry of Science and Technology, the Ministry of Education and Human Resources etc. Agencies led by government include Biotechnology Industry Association, Biotechnology Venture-capital Association and Biotechnology Research Association etc. Ministries take responsibility for different areas and links in research, development and industrialization of biotechnology, which can work out closely according to the demand. It is shown that the division of their labour is clear and scientific. Due to the characteristics of the high-risk and high-return, biological industry extremely urges for scientific and reasonable planning. In recent years, according to the international trend of biotechnological industry and its domestic condition, Republic of Korea launched a series of planning including "National Biotechnology Research and Development Program” (1992), "Biotechnology 2000 Plan" (1994-2006), "Biotechnological Industry Vision 2000 Plan" (1994), "National Technology Map" (2006), "Bio - Vision2016" (2006), "The Third Republic of Korea Vision Plan" (2008) etc. [9] in order to promote $21^{\text {st }}$-century biological industry development of Korea and make it go out into the world.

\section{Diverse Operation and Emphasis on Cooperation}

The operation of Republic of Korea research institutions have three types, that is, national research institute, university research institute and nongovernmental research institute. The government provides full fund for fundamental and applied research of national research institutes and university research institutes and they also participate in some long-time national research project took by enterprise $R \& D$ institutes. Nongovernmental institutes, including enterprise research institute, profit corporation research institute, non-profit corporation research institute, industrial technology research composition and nongovernmental technology research institute, take the leading position in the Korean research strength and most of their research results transformed directly into productivity. In addition to the various and flexible operation mechanism, Korea also actively carries out international cooperation in the field of biotechnology and attracts foreign investment in order to construct global joint research system. Since 1985, Korea launched "International Joint Research Project" to provide political and financial support for bilateral cooperation. In 2004, this project has funded 1896 international cooperative research project [10]. "International Cooperation Coordination Committee" comes into existence at the same time, which takes the responsibility to set down international cooperation plan and policy and establish joint development strategy of fundamental and applied technology. Overseas biological companies which establish production and research bases in Korea will receive special preferential policies provided by the government, such as tax reduction, cash assistant and employment opportunities etc.

\section{Problems and Solutions}

As a result of the slump of the global and domestic economy, the pace of the biotechnological industry development in Japan slowed significantly in recent years. In
2005, science and technology literature on biotechnological industry of Japan ranked the $4^{\text {th }}$ in the world, while the number of patent applications $2^{\text {nd }}$ and market value $2^{\text {nd }}$ [5], which shows that Japan still occupies the leading position in the field of biotechnology [3]. However, according to its market value growth in recent years (1.76 trillion yen in 2005, 8 trillion yen in 2008), there is a long distance towards the aim of 2020 vision.

From the authors' point of view, Japan could further intensify policy promotion in the following four aspects: one is to continue to carry on the successful experiences and consolidate the existing advantages. By reform of institutions and systems, Japan can further promote the transformation of scientific research achievements and better combine the university, industry and cooperation; it can further strengthen the interdisciplinary by combining biotechnology with those leading industry technologies such as intelligence, electronics, machinery, etc. The second one is to optimize and correct the policies promptly. Even though Japan had a clear aim when it made policies, Japan failed in the process of implementation in dealing with those specific issues, which caused that in recent years, the development of biological industry did not meet the plan [11], so it is important to make prompt feedback to the practical problems in the process of industrialization of science and technology. In addition, frequent power change in Japan put forward higher request for the continuity and prompt revision of policies. The third one is guidance of policies. Making use of biotechnology promotes energy-saving and low-carbon industries in order to keep the promise of 2020 carbon dioxide emission reduction. The Fourth one is to vigorously support the development of biological industry derivative markets. With the vigorous development of biological industry in Japan, derivative economy lead by biological services is in the ascendant. According to the statistics, market scale of Japan's biological service industry was 243.4 billion yen in 2005 , increased by $10.5 \%$ than that of 2004. There is no doubt that market scale of biological service will grow rapidly in the future.

The Republic of Korean government devoted a large number of investments on industry, and the annual investment continues to rise at a rate of $20 \%$ or more. The governmental investment on biotechnology was more than 5.2 trillion between 2000 and 2007 [12]. But in terms of absolute amount, Korea is still far behind Japan, and even been surpassed by China, a rising star from the three most powerful countries in East Asia. Except that the investment amount should be increased, the structure also should be optimized. Although the Korean government always encourages companies to invest, the amount of company investment is barely equal to that of governmental investment from 1994 to 2006. During 2001 to 2004, company investment is even lower than the average governmental investment. Calculated by annual growth rate of investment, $17.5 \%$ from company investment is much lower than $27.5 \%$ from the governmental investment [12]. In terms of organizational strategy, as mentioned above, the Korean government have adopted the principle of "fine division" when it set the competent authorities of biological 
industry, such as Ministry of Commerce, Industry and Engineering (MOCIE) for management of applied biotechnologies and develop alternative energies, Ministry of Science and Technology (MOST) for fundamental and cutting-edge technology research, Ministry of Education (MOE) for help to support basic research of life science, Ministry of Health and Welfare (MOHW) for management and support for new biological drugs, Ministry of Agriculture and Forestry (MAF) for management of transgenic plants and animals and research and development of new food additives, Ministry of Environment (ME) for the preservation and utilization of biological resources and development of waste treatment technology, Ministry of Marine and Fishery (MOMAF) for management and support of protection of marine resources and research on marine biological genes, Korean Food and Drug Administration (KFDA), etc. Even though this kind of organizational structure has a clear division of responsibilities, but it is not propitious to provide support for interdisciplinary research and its industrialization.

All in all, Republic of Korean biological industry policies should be enhanced in the following aspects. One is to encourage company and private capital to invest. The second one is to improve the public research system and strengthen the overall management. In order to distribute fund of research and development effectively and avoid repetition of investment and overlapping management of departments, the Korean government established the office of scientific and technological innovation in 2004, but as it didn't own the administrative effectiveness towards other departments, which weakened its effect. Under the established management system, it may function as the intermediary to build up bridges among the government, research institutions, companies and investment institutions and form a network combined policy, scientific research, investment and industry into one. The third one is to further make clear and stand out the advantages, protect and inaugurate the traditional biological industry. Beside the strong international competitiveness that the fermentation industry holds, Korea has breakthrough advantages in stem cell research and biological medicine, etc. In the field of traditional food brewing, it desperately requires the transformation and upgrading of existing technology and expansion of overseas markets for traditional food.

\section{Prospects}

The $21^{\text {st }}$-century is the era of life science and biological industry, and Japan and Republic of Korea has been in the forefront. After experiencing a late-start, fast-development, small-scale and low-marketization primary stage, the biological industry in China also arrives at a turning point and faces to significant challenges and opportunities. In 2011, "The Twelfth Five-year Plan for National Economic and Social Development of the People's Republic of China" [13] put forward that "cultivate strategic new-emerging industries into the pilot and pillar industries". Among these priority industries, biological industry ranks the third. In 2013, China State Council launched "Biological Industry Development Plan", in which made the biological industry development goals clear, i.e. by 2015 , biological industry will form distinctive industrial development abilities, significantly enhance its ability to make contributions to the economic and social development and occupy a good position in the competition pattern of global industries; by 2020, the biological industry will become the pillar industry of the national economy [14]. Based on the above analysis and study, developing new-emerging biological industry and forming remarkable social benefits must be supported by more effective policies and guidance, rationalized structure, and strengthened innovation ability, improved scale, quality and the environment. It is expected that the policy experience of Japan and Republic of Korea provides a good reference to the development and prosperity of biological industry in China during "Twelfth Five-year".

\section{References}

[1] Biotechnology Strategy Council of Japan, "Biotechnology Strategy Guideline," December 2002.

[2] Zheng Fengtian, Xin Bensheng, "Policy Review and Implications of the Biotechnology Industry in Japan," Scientific research, Vol. 24 (supp.), pp. 486-489, 2006.

[3] Zhang Zhiran, Diao Tianxi, Gao Yunhua, "Status and Prospect of the bio-pharmaceutical industry in Japan," Chinese Medicine, Vol. 7, no. 1, pp. 141-143, 2010.

[4] The Government of Japan, "The Science and Technology Basic Plan (2001-2005)," Tokyo, 2001

[5] Japan External Trade Organization, "Attractive sectors, biotechnology," October 2007

[6] Sun Guofeng, "the biotechnology industry revitalization strategies of Japan five ministries and agencies," Biotechnology Information, Vol. 1, pp. 51, 2000.

[7] Yuan Shisheng, "The Basic Breeding Plan Of Korea Bioengineering And Industrialization Supportive Policy" Global Technology Economic Outlook, Vol. 2, pp. 16-17, 2000.

[8] Peng Haoshu, Wang Yongli, Deng Xinan, "Aspects of South Korea scientific and technological innovation," World Science and Technology Research and Development, Vol. 27, no. 1, pp. 92, 2005.

[9] Liu Ying, "Korean Bio-Technology R \& D Development Status And Future," Investment of Science and Technology of China, Vol. 3, pp. 78-79, 2009

[10] Ming Jingji, Qian Wei, "The Course of Development of Science and Technology Policy in Korea since 1960," Science Research, Vol. 21, no. 6, pp. 603-608, 2003.

[11] Mark Lehrer, Kazuhiro Asakawa, "Rethinking the public sector: idiosyncrasies of biotechnology commercialization as motors of national R\&D reform in Germany and Japan," Research Policy, Vol. 33, 921-938, 2004.

[12] Joseph Wong, Uyen Quach, Halla Thorsteinsdottir, et al., "South Korean biotechnology arising industrial and scientific powerhouse," Nature Biotechnology, Vol. 22 (supp.), pp. 42-47, 2004

[13] Xinhua News Agency, "Outline of the 12th Five-Year Plan for National Economic and Social Development," March 16, 2011.

[14] The Central People's Government of the P.R. China, "Notice of the State Council on the issuance of the bio-industry development plan," http: //www.gov.cn/zwgk/2013-01/06/content_2305639.htm, January 2013. 